\title{
Article \\ The Effect of Aging on Precipitates, Mechanical and Magnetic Properties of Fe-21Cr-15Ni-6Mn-Nb Low Magnetic Stainless Steel
}

\author{
Changsheng $\mathrm{Li}^{1, *} \mathbb{1}, \mathrm{Kun} \mathrm{Li}^{1}$, Jingbo Dong ${ }^{1}$, Jinyi Ren ${ }^{1}$ and Yanlei Song ${ }^{2, *}$ \\ 1 State Key Laboratory of Rolling and Automation, Northeastern University, Shenyang 110819, China; \\ likunneu@163.com (K.L.); neudong23@163.com (J.D.); renjinyi0717@163.com (J.R.) \\ 2 Panassonic Appliances Compressor (Dalian) Co., Ltd., Dalian 116033, China \\ * Correspondence: lics@ral.neu.edu.cn (C.L.); songyanlei@papcdl.panasonic.cn (Y.S.); \\ Tel.: +86-2483-6877-49 (C.L.)
}

check for updates

Citation: Li, C.; Li, K.; Dong, J.; Ren, J.; Song, Y. The Effect of Aging on Precipitates, Mechanical and Magnetic Properties of Fe-21Cr-15Ni-6Mn-Nb Low Magnetic Stainless Steel. Metals 2021, 11, 819. https://doi.org/ $10.3390 /$ met11050819

Academic Editor: Antonio Mateo

Received: 22 April 2021

Accepted: 11 May 2021

Published: 18 May 2021

Publisher's Note: MDPI stays neutral with regard to jurisdictional claims in published maps and institutional affiliations.

Copyright: (c) 2021 by the authors. Licensee MDPI, Basel, Switzerland. This article is an open access article distributed under the terms and conditions of the Creative Commons Attribution (CC BY) license (https:// creativecommons.org/licenses/by/ $4.0 /)$.

\begin{abstract}
The effect of aging on the precipitates, mechanical and magnetic properties of $\mathrm{Fe}-21 \mathrm{Cr}-$ $15 \mathrm{Ni}-6 \mathrm{Mn}-\mathrm{Nb}$ low magnetic stainless steel were investigated. The steel was aged at $550-750{ }^{\circ} \mathrm{C}$ for $2 \mathrm{~h}$ after solution heat treatment at $1100{ }^{\circ} \mathrm{C}$ for $1 \mathrm{~h}$. During the aging treatment, the $(\mathrm{Nb}, \mathrm{V})(\mathrm{C}, \mathrm{N})$ particles gradually precipitated in the grain, which were coherent or semi-coherent with the matrix. When the aging temperature was beyond $650{ }^{\circ} \mathrm{C}$, the coarsening rate of $(\mathrm{Nb}, \mathrm{V})(\mathrm{C}, \mathrm{N})$ particles increase rapidly and the coherent orientation between $(\mathrm{Nb}, \mathrm{V})(\mathrm{C}, \mathrm{N})$ particles and the matrix was lost gradually. Meanwhile, coarse $\mathrm{M}_{23} \mathrm{C}_{6}$ was distributed at the grain boundary with chain shape, which was non-coherent with the matrix. The coarsening behavior of $(\mathrm{Nb}, \mathrm{V})(\mathrm{C}, \mathrm{N})$ precipitates in the grain was analyzed, and the size of the particles precipitated after aging treatment at $650^{\circ} \mathrm{C}$ for different time was calculated and studied. After aging treatment at $650{ }^{\circ} \mathrm{C}$ for $2 \mathrm{~h}$, the yield strength and tensile strength of the stainless steel was 705.6 MPa and 1002.3 $\mathrm{MPa}$, the elongation and the relative magnetic permeability was $37.8 \%$ and 1.0035 , respectively.
\end{abstract}

Keywords: stainless steel; aging treatment; precipitate; orientation; magnetic properties

\section{Introduction}

Compared with ferritic and martensitic stainless steels, austenitic stainless steels (ASSs) have advantages in ductility, toughness, corrosion resistance and creep strength [1,2]. It has been extensively researched and widely used in the nuclear power, aviation and military industries [3,4]. In terms of the stable ASSs, it can avoid being magnetized in magnetic field due to the paramagnetic property of austenite, so called low-magnetic stainless steels [5]. Low-magnetic stainless steels have been applied on critical and serious area, such as components in electronic instruments, large-scale nuclear fusion equipment, naval submarines for providing protection against magnetic detection and undersea mines [6].

With regard to low magnetic stainless steels, the primary strategy to obtain low permeability is to ensure the stability of austenite during deformation or heat treatment; however, the strength of traditional ASSs is considerably low. For instance, the yield strength and tensile strength of SUS304 stainless steel are 200-400 MPa and 600-750 MPa, respectively [7]. For the strengthening of unstable ASSs, the inverse transformation of strain induced martensite through annealing procedure after cold or cryogenic rolling is widely adopted by many researchers [8,9]. However, due to the absence of phase transformation in low-magnetic stainless steels, strengthening mechanism is consisted with precipitation hardening of fine particles homogenously distributed throughout the matrix and solution strengthening with the addition of elements of $\mathrm{Cr}, \mathrm{Ni}, \mathrm{Mo}, \mathrm{Nb}, \mathrm{V}$, etc. $[10,11]$. Precipitates play a crucial role in stabilizing the microstructure, inhibiting the grain growth and suppressing the recrystallization of low-magnetic stainless steels. As potential nanosized precipitates in stainless steels, carbides, nitrides, $\mathrm{Cu}$-rich precipitates, nickel aluminide, oxides and many 
other types of precipitates have been investigated [12-16]. Long-term aging at elevated temperatures tend to facilitate elemental diffusion and thus cause precipitates coarsening, which consequently results in degradation in the microstructure and mechanical properties [17]. For instance, in $19 \mathrm{Cr}-0.4 \mathrm{Nb}$ ferrite stainless steels, coarsening of the $\mathrm{Fe}_{3} \mathrm{Nb}_{3} \mathrm{C}$ precipitates lead to the degradation in high temperature strength and thermal fatigue resistance during the long-term service at 1073-1173 K [18]. The main reason for the decrease at high temperature strength of $310 \mathrm{~S}$ austenitic stainless steel is the coarsening of Laves phase during long time aging treatment [11]. Therefore, understanding of microstructure stability in aging treatment, particularly the thermal stability of all the precipitates, and its effects on mechanical properties is vital for applications of low-magnetic stainless steels. Furthermore, there are few studies on the effect of precipitation on the magnetic properties for low-magnetic stainless steels.

The specific orientation relationship and interface structure between the precipitates and the matrix can effectively hinder the movement of dislocations [19]. The coarsening behavior of the precipitates and mechanical behavior are affected by the orientation relationship [20]. It has been reported that the small block of $\mathrm{M}_{23} \mathrm{C}_{6}$ become spherical because the coherent relation between $\mathrm{M}_{23} \mathrm{C}_{6}$ and matrix is lost in Fe-Cr-Ni-Mn-Mo-V-Nb super alloy [21]. Trotter et al. reported a sufficient tensile ductility of an aged alumina-forming stainless austenitic steel and attributed this to a moderate misfit between the Laves phase and austenite matrix [22]. Due to the low interfacial energy of the semi-coherent relationship between the $\mathrm{NbC}$ and the matrix, the diffusion of $\mathrm{Nb}$ atoms is difficult, and the nano- $\mathrm{NbC}$ has stronger resistance to coarsening than $\mathrm{M}_{23} \mathrm{C}_{6}$ in $310 \mathrm{~S}$ austenitic stainless steel [11]. Considering that the coarsening of precipitates is unavoidable at high temperatures, it is of great importance to study the change of orientation relationship with the coarsening of precipitates in low-magnetic stainless steels.

The precipitation, mechanical and magnetic properties of Fe-21Cr-15Ni-6Mn-Nb low magnetic stainless steel were investigated in this paper. The precipitates evolution through aging treatment for low magnetic stainless steel were investigated. The coherent or semi-coherent relationship of $(\mathrm{Nb}, \mathrm{V})(\mathrm{C}, \mathrm{N})$ precipitates with the matrix in the aging treatment were researched. The coarsening behavior of intragranular $(\mathrm{Nb}, \mathrm{V})(\mathrm{C}, \mathrm{N})$ particles during the aging process were analyzed by LSW theory. The relative magnetic permeability of experimental steel with different aging process was studied. These studies can promote the research and application of high strength low magnetic stainless steel.

\section{Materials and Experiments}

\subsection{Fabrication of the Experimental Steel}

The chemical composition of the experimental steel is shown in Table 1. The preparation process of the experimental steel is as follows: (1)The cylindrical steel ingot with diameter of $\Phi 250 \mathrm{~mm}$ and weight of $75 \mathrm{~kg}$ was obtained by vacuum induction smelting; (2) the ingot is forged into a billet of $100 \mathrm{~mm} \times 100 \mathrm{~mm} \times 50 \mathrm{~mm}$; (3) the billet of $100 \mathrm{~mm}$ $\times 100 \mathrm{~mm} \times 50 \mathrm{~mm}$ is placed in a heating furnace(Boda Electric Furnace, Xi'an, China) for high temperature homogenizing treatment at $120{ }^{\circ} \mathrm{C}$ for $2 \mathrm{~h}$, followed by hot rolling in a $\Phi 450 \mathrm{~mm}$ two-roll reversible hot mill, after 9 passes of hot rolling, a hot rolled sheet with a thickness of $4.5 \mathrm{~mm}$ was obtained, the starting temperature and finishing temperature of hot rolling are $1160^{\circ} \mathrm{C}$ and $940{ }^{\circ} \mathrm{C}$, respectively, after hot rolling the steel sheet was cooled by water; (4) solution treatment of experimental steel was performed at $1100{ }^{\circ} \mathrm{C}$ for $1 \mathrm{~h}$; (5) after solution treatment, the experiment steel was aging treated at 550, 600, 650, 700 and $750{ }^{\circ} \mathrm{C}$ for $2 \mathrm{~h}$. 
Table 1. The chemical composition of the experimental steel (mass, \%).

\begin{tabular}{cccccccccc}
\hline $\mathbf{C}$ & $\mathbf{S i}$ & $\mathbf{M n}$ & $\mathbf{M o}$ & $\mathbf{N i}$ & $\mathbf{C r}$ & $\mathbf{N b}$ & $\mathbf{V}$ & $\mathbf{N}$ & Bal \\
\hline 0.18 & 0.203 & 5.9 & 0.50 & 14.85 & 20.25 & 1.34 & 0.35 & 0.368 & $\mathrm{Fe}$ \\
\hline
\end{tabular}

\subsection{Microstructural and Properties Characterisation}

The phase analysis was carried out by XRD (Bruker D8, Leipzig, Germany). The measured diffraction angle ranged from 20 to $100^{\circ}$, the scanning speed was $2 \% / \mathrm{min}$, the anode target was $\mathrm{Cu}$ and the sample was prepared by electrolytic polishing. Electrolytic polishing solution was made by mixing perchloric acid, acetic acid and ethanol solution. The specific ratio was $\mathrm{V}$ (perchloric acid): $\mathrm{V}$ (acetic acid): $\mathrm{V}$ (alcohol) $=2: 1: 7$, polishing voltage is $25-30 \mathrm{~V}$, polishing time is 25 to $32 \mathrm{~s}$ and electrolytic polishing temperature is ambient temperature. The morphology of the precipitates was observed by SEM (ZEISS ULTRA 55, Hallbergmoos, Germany). The steps of sample preparation and the corresponding parameters are as follows: Electrolytic corrosion of grinded and polished specimens was performed at ambient temperature, the etching solution was $60 \%$ aqueous nitric acid solution and the corrosion voltage was $25-35 \mathrm{~V}$. The corrosion current is 1.5 to $1.8 \mathrm{~A}$, and the corrosion time is 25 to $35 \mathrm{~s}$. The precipitated particles were further observed by TEM (FEI Tecnai G2 F20, Hillsboro, OR, USA) with an acceleration voltage of $200 \mathrm{kV}$. The sample was first mechanically thinned to $50 \mu \mathrm{m}$ and then subjected to electrolytic double spray thinning at $32 \mathrm{~V}$ and $-30{ }^{\circ} \mathrm{C}$ by double spray thinner (Struers TenuPol-5, Copenhagen, Denmark) to form a film sample. The electrolyte was composed of $9 \%$ perchloric acid and $91 \%$ absolute ethanol.

The tensile tests were carried out on electronic universal tensile testing machine (CMT 5105 , Kexin, Changchun, China) at a tensile speed of $3 \mathrm{~mm} / \mathrm{min}$, and three samples were tested for each process to take the average value. Magnetic properties of experimental steel were measured through vibrating sample magnetometer (VSM Lake Shore 7407, Changchun, China) with magnetic field strengths ranging from $-5 \mathrm{kOe}$ to $+5 \mathrm{kOe}$.

\section{Results}

\subsection{Thermodynamic Calculation of Precipitates}

Figure 1 shows the relationship between the molar mass of precipitates and temperature in the equilibrium state of experimental steel calculated by Thermal-Calc thermodynamic software. As is shown in Figure 1a, the precipitates mainly include FCC_A1\#2, Z phase, $\mathrm{M}_{23} \mathrm{C}_{6}$ and $\sigma$ phase in the temperature range of $400-1600^{\circ} \mathrm{C}$. Figure $1 \mathrm{~b}$ is the enlargement of Figure 1a. FCC_A1\#2 is the preferred precipitate at $1145^{\circ} \mathrm{C}$ with the decrease of temperature, followed by $\mathrm{Z}$ phase and $\mathrm{M}_{23} \mathrm{C}_{6}$. The dissolution temperature of these precipitates is about $1020^{\circ} \mathrm{C}$, which is higher than $660^{\circ} \mathrm{C}$ of hard brittle $\sigma$ phase. Over the entire calculated temperature range, the amount of FCC_A1\#2 remained stable, while the precipitation of $\mathrm{M}_{23} \mathrm{C}_{6}$ decreased sharply with the increase of temperature. Due to the forming of stable carbonitrides with $\mathrm{Nb}$ and $\mathrm{V}$ preferentially combined with $\mathrm{C}$ and $\mathrm{N}$, the $\mathrm{C}$ and $\mathrm{N}$ content in the matrix is reduced, and the precipitation of $\mathrm{M}_{23} \mathrm{C}_{6}$ as well as $\mathrm{Z}$ phase are inhibited. In addition, the content of $\sigma$ phase decreases sharply with the increase of temperature. 

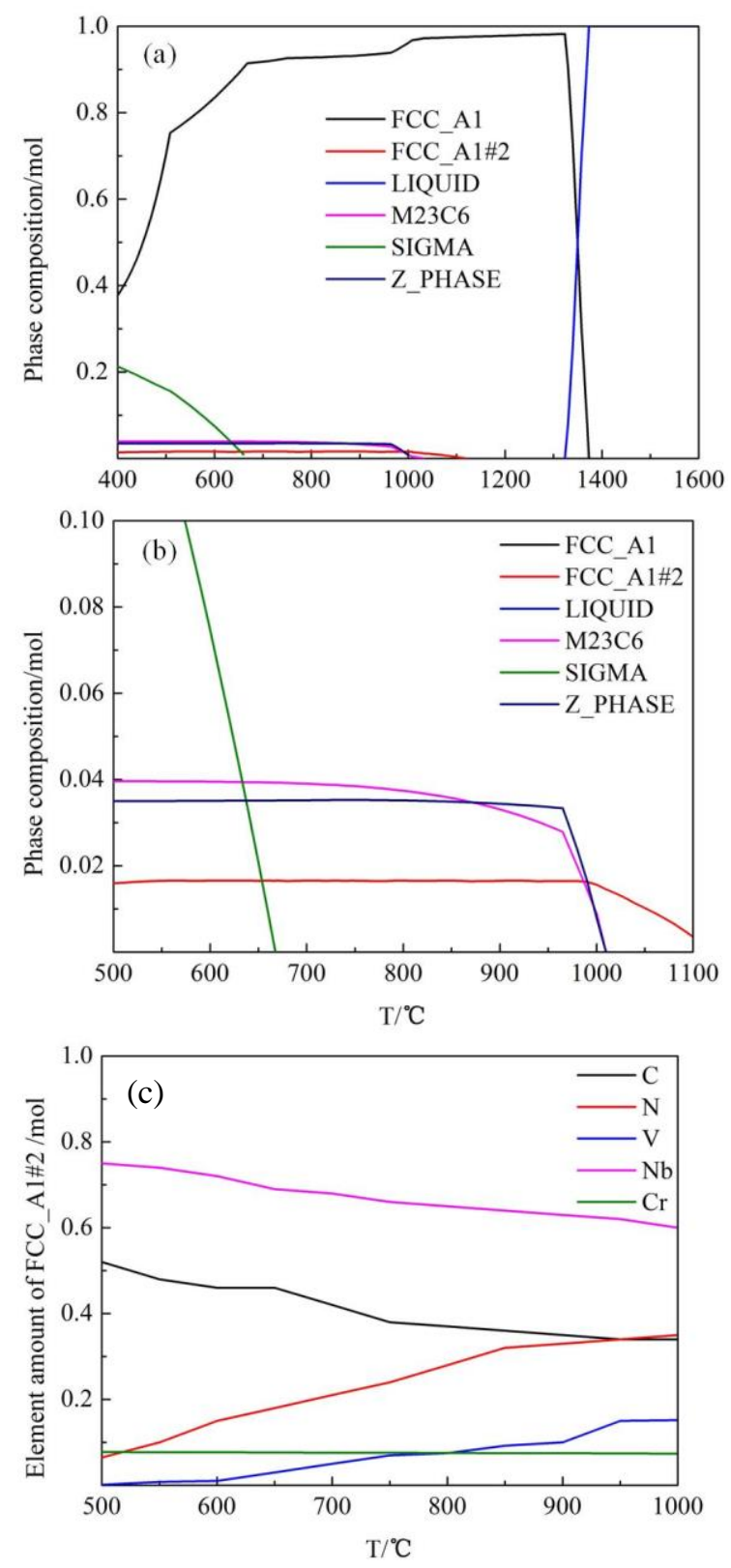

Figure 1. Equilibrium phase fractions of precipitates for experimental steel calculated by ThermalCalc. (a) 0 1 mol of $\mathrm{Y}$ axis, (b) 0 0.1 mol of $\mathrm{Y}$ axis, (c) variation of $\mathrm{C}, \mathrm{N}, \mathrm{V}, \mathrm{Nb}$ and $\mathrm{Cr}$ in FCC_A1\#2.

Figure 1c shows the main element components of FCC_A1\#2. The change trend of elements with temperature is very similar to the results of Han et al. [23]. It can be inferred that the precipitation phase is relatively complex carbonitride $(\mathrm{Nb}, \mathrm{V})(\mathrm{C}, \mathrm{N})$. In the aging process, the types and morphology of precipitates will be further analyzed.

\subsection{Microstructure after Solution Treatment}

Figure 2 shows the scanning electron micrograph and EDS of the experimental steel after solution treatment. The microstructure was uniform austenite equiaxed grain. The average grain size was $13( \pm 2.6) \mu \mathrm{m}$ in diameter via the Image Pro Plus image processing software. A small amount of granular precipitates existed at grain boundaries in the structure of experiment steel (indicated by the red circle in Figure 2a, and the sizes of granular precipitates were all below $0.1 \mu \mathrm{m}$. From the energy spectrum analysis of precipitates in Figure $2 \mathrm{~b}$, the $\mathrm{Nb}$ content in granular precipitates is highest. 



Figure 2. Microstructure of solution-treated experimental steel. (a) SEM of solution-treated experimental steel, the precipitates on the grain boundary are marked with red circles, $(\mathbf{b})$ energy spectrum analysis of precipitates.

Through TEM observation and diffraction spot calibration, the granular precipitate can be determined as $\mathrm{Nb}(\mathrm{C}, \mathrm{N})$, which is a typical face-centered cubic structure with a lattice constant of $0.447 \mathrm{~nm}$ [24], as shown in Figure 3. These granular $\mathrm{Nb}$ carbonitrides were formed during the solidification and could not be completely dissolved during subsequent hot rolling experiments and solution treatment. If the residual $\mathrm{Nb}(\mathrm{C}, \mathrm{N})$ particles are excessive after solution treatment, the content of $\mathrm{Nb}$ in the experimental steel will decrease, and the effect of precipitation strengthening in aging treatment will be greatly reduced. In the present study, since the diameter of $\mathrm{Nb}(\mathrm{C}, \mathrm{N})$ precipitates at the grain boundary was less than $100 \mathrm{~nm}$ and the distance between them is more than $10 \mu \mathrm{m}$, the residual $\mathrm{Nb}(\mathrm{C}$, $\mathrm{N})$ particles in solution treatment had no effect on the microstructure and properties of experimental steel with aging treatment [25].
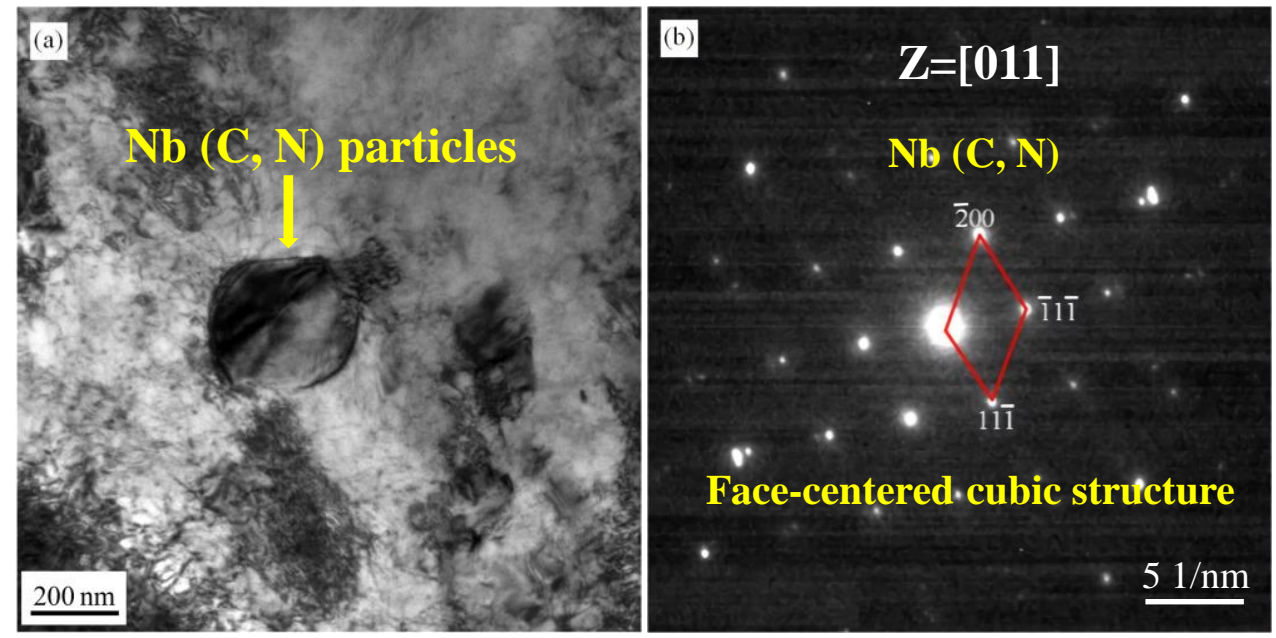

Figure 3. TEM morphology of the steel after solution treatment. (a) Bright field image of retained particles, (b) diffraction pattern calibration of precipitates.

\subsection{Microstructure after Aging Treatment}

The experiment steel was aging treated at 550, 600, 650, 700 and $750{ }^{\circ} \mathrm{C}$ for $2 \mathrm{~h}$. The result of XRD phase analysis and SEM observation were shown in Figure 4 . It can be seen from Figure $4 \mathrm{a}$ that the diffraction peak of the $\gamma$ phase is the strongest in the curves. The second phase particles mainly consisted of MX-type particles and $\mathrm{M}_{23} \mathrm{C}_{6}$. With the temperature increases in the aging treatment, the diffraction peak of MX-type particles gradually increased. The strongest diffraction peak of MX-type particles existed at $650{ }^{\circ} \mathrm{C}$. Further increasing the temperature, the diffraction peak of MX-type particles decreased gradually. 

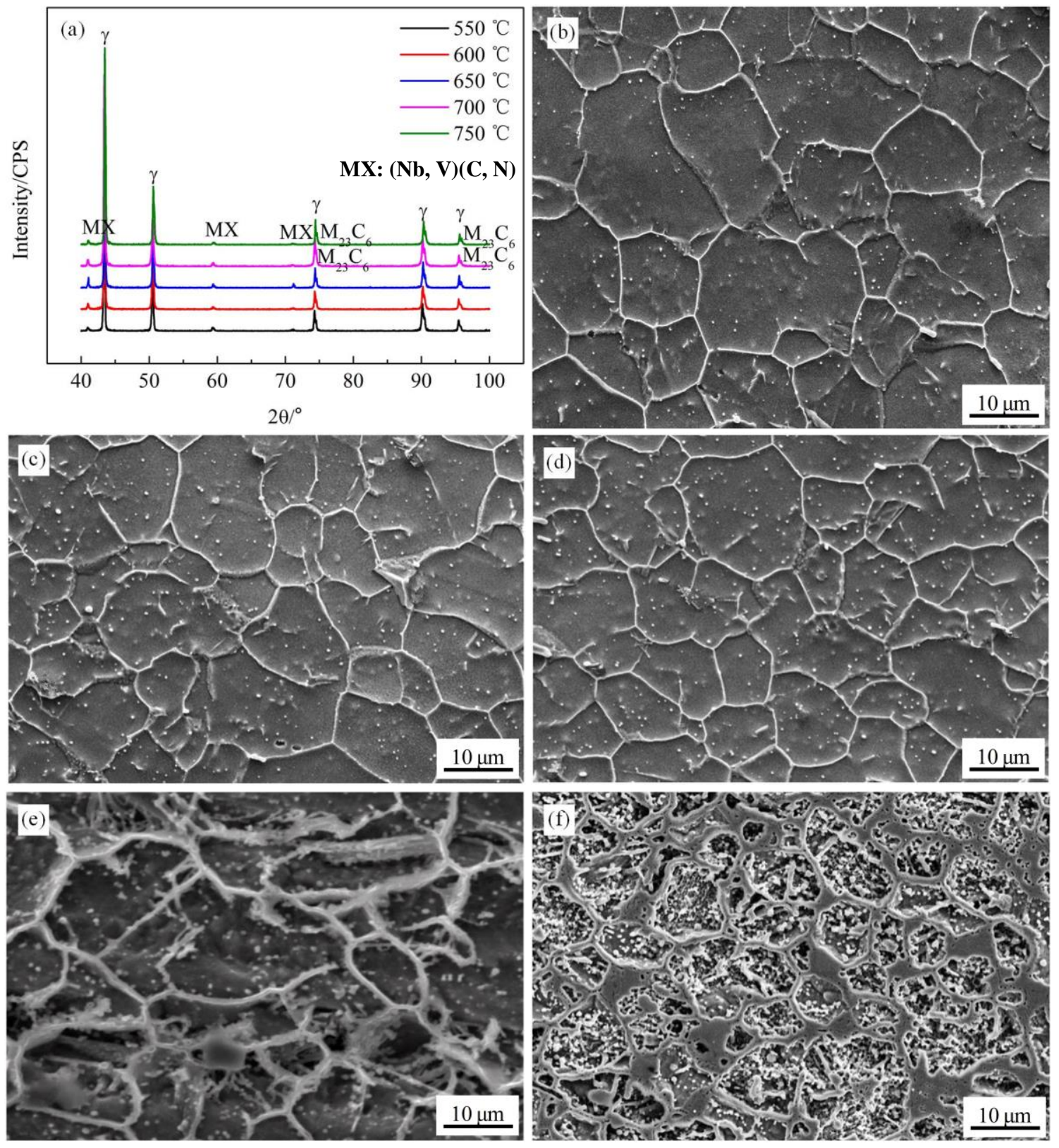

Figure 4. XRD and SEM of the specimens aged at different temperature for $2 \mathrm{~h}$. (a) XRD analysis, (b) $550{ }^{\circ} \mathrm{C},(\mathbf{c}) 600{ }^{\circ} \mathrm{C}$, (d) $650{ }^{\circ} \mathrm{C},(\mathbf{e}) 700^{\circ} \mathrm{C},(\mathbf{f}) 750{ }^{\circ} \mathrm{C}$.

After aging treatment at different temperatures, the grain size of the steel remained stable. When the aging temperature was $550{ }^{\circ} \mathrm{C}$, a small amount of spherical particles occurred in the grain (Figure $4 \mathrm{~b}$ ). When the aging temperature increased to 600 and $650{ }^{\circ} \mathrm{C}$, the spherical particles were dispersed in the crystal. The size of the precipitates remained unchanged, and amount of the precipitates increased (Figure 4c,d). When the aging temperature was $700{ }^{\circ} \mathrm{C}$, the grain boundaries began to coarsen, due to the aggregation of precipitates at grain boundaries. And the size of intragranular particles gradually increased (Figure 4e). When the aging temperature increased to $750{ }^{\circ} \mathrm{C}$, the entire scanning area had been connected into a network structure. The coarse particles in the crystal existed in irregular shapes. And the width of the aggregation of precipitates at grain boundaries had been increased to about $2.5 \mu \mathrm{m}$ (Figure $4 \mathrm{f}$ ). This kind of microstructure will have a very adverse effect on the comprehensive properties of the steel.

Figure 5 shows the TEM and the energy spectrum analysis of the precipitated particles after aging treatment at $650{ }^{\circ} \mathrm{C}$ for $2 \mathrm{~h}$. As shown in Figure $5 \mathrm{a}$, the fine spherical precipitates 
were dispersed in the grain, with the average diameter of $28 \mathrm{~nm}$. The TEM-EDS analysis of the precipitates were shown in the upper right of Figure 5a. The results of EDS show that the content of niobium in the precipitates was the highest, which was consistent with the thermodynamic calculation. Because of high $\mathrm{Cr}, \mathrm{Nb}$ and $\mathrm{N}$ in the steel, it was easy to form Z-phase $(\mathrm{NbCrN})$ particles in aging treatment at high temperature [23]. Therefore, it needs further observation and analysis to identify the precipitates. In terms of composition, the contents of $\mathrm{Cr}$ and $\mathrm{N}$ are usually higher in $\mathrm{Z}$ phase [26]. In addition, the precipitates in the grain were spherical or ellipsoidal (Figure 5a), while the $Z$ phase is usually rod-shaped $[27,28]$. Combined with TEM diffraction spot calibration, it can be further determined that the precipitated particles are $(\mathrm{Nb}, \mathrm{V})(\mathrm{C}, \mathrm{N})$ with face centered cubic (FCC) structure and have cubic-on-cubic orientation with austenite matrix, as shown in Figure $5 \mathrm{~b}$. In the isothermal process, $\mathrm{Nb}(\mathrm{C}, \mathrm{N})$ nucleates preferentially, while $\mathrm{V}(\mathrm{C}, \mathrm{N})$ shows a characteristic of epitaxial precipitation. Once $\mathrm{Nb}(\mathrm{C}, \mathrm{N})$ is formed, $\mathrm{V}(\mathrm{C}, \mathrm{N})$ begins to nucleate in shell or cluster around it, but the structure remains unchanged $[27,28]$. The mismatch between $(\mathrm{Nb}, \mathrm{V})(\mathrm{C}, \mathrm{N})$ and austenite matrix was calculated to be $17.6 \%$, which indicates that $(\mathrm{Nb}, \mathrm{V})(\mathrm{C}, \mathrm{N})$ are always semi-coherent with the austenite matrix after aging treatment at $650{ }^{\circ} \mathrm{C}$ for $2 \mathrm{~h}$. It can be observed in the Figure $5 \mathrm{a}, \mathrm{b}$ that it is the dislocation cutting mechanism when the precipitates are small and coherent with the matrix. The schematic diagram of dislocation cutting mechanism is as shown in Figure 5c. Due to the different crystal constants between the precipitates and the matrix, a part of dislocation energy exists. After the dislocation cuts through the precipitated phase, the interfacial energy increase with the increasing interfacial area. The stress field around the particle interact with the dislocation stress field, which hinder the dislocation movement. It is a process of energy rising when the dislocation cuts through the particle, which make the dislocation slip difficult and the steel strengthened.


Figure 5. TEM analysis of the precipitates in specimens aged at $650{ }^{\circ} \mathrm{C}$ for $2 \mathrm{~h}$. (a) The bright field image and energy spectrometer detection of the particles, (b) diffraction patterns of the particles, (c) the schematic diagram of dislocation cutting mechanism. 
Figure 6 shows the TEM morphology of precipitated particles after aging treatment at $750^{\circ} \mathrm{C}$ for $2 \mathrm{~h}$. The morphology of $(\mathrm{Nb}, \mathrm{V})(\mathrm{C}, \mathrm{N})$ particles are large block or ellipsoid and the average diameter of $(\mathrm{Nb}, \mathrm{V})(\mathrm{C}, \mathrm{N})$ particles was $253 \mathrm{~nm}$ (Figure 6a). In general, $\mathrm{Nb}$-rich carbonitrides are preferentially precipitated at the $\{111\} \gamma$ plane $[29,30]$. But in this study, the diffraction spots of the precipitated phase do not all appear under the same low-index ribbon axis (the red circular frame portion in Figure $6 \mathrm{~b}$ by calibrating the coarse $(\mathrm{Nb}, \mathrm{V})(\mathrm{C}, \mathrm{N})$ diffraction patterns. It can be determined that the original cubic-cubic orientation between coarsened $(\mathrm{Nb}, \mathrm{V})(\mathrm{C}, \mathrm{N})$ particles and matrix has been lost, which means the coherent relationship with the matrix is gradually lost with the coarsening of $(\mathrm{Nb}, \mathrm{V})(\mathrm{C}, \mathrm{N})$. At the trigeminal boundary, a discontinuous cell or sheet structure was observed. It is found by diffraction pattern calibration that the precipitated particle was $\mathrm{M}_{23} \mathrm{C}_{6}$ (Figure 6c) showing a non-coherent orientation with the matrix, as shown in Figure $6 \mathrm{~d}$. The deformation mechanism transfer from cutting to bowing out when the hard particles are large and incoherent with the matrix, as shown in Figure 6a. The schematic diagram of dislocation bypass mechanism is as shown in Figure 6e. When the dislocations sweep through the large precipitates, the dislocations would bypass the particles and continued to move. The dislocation line will bend when it bypasses the particles. When the bending of dislocation line is serious, the two ends of the dislocation line will meet and the dislocation will continue to move forward with leaving a dislocation loop. The energy increases due to stretch the dislocation in bending process. Therefore, the dislocations are difficult to move and the alloy is strengthened.
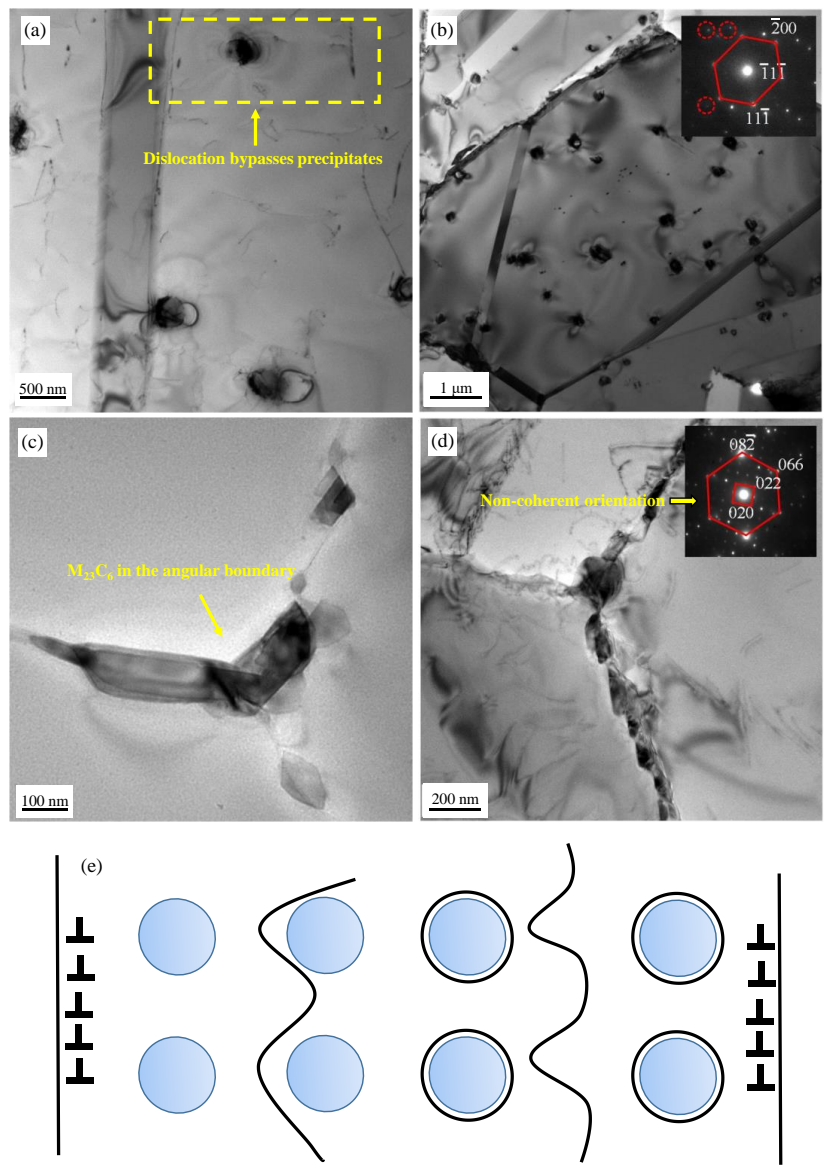

Figure 6. TEM analysis of the precipitates in specimens aged at at $750{ }^{\circ} \mathrm{C}$ for $2 \mathrm{~h}$. $(\mathbf{a}, \mathbf{b})$ The bright field image and diffraction patterns of the coarsening $(\mathrm{Nb}, \mathrm{V})(\mathrm{C}, \mathrm{N})$ particles, $(\mathbf{c}, \mathbf{d})$ the bright field image and diffraction patterns of $\mathrm{M}_{23} \mathrm{C}_{6}$ in the angular boundary, (e) the schematic diagram of dislocation bypass the particles mechanism. 


\subsection{Mechanical Properties}

Figure 7 shows the tensile curves and mechanical properties of the experimental steel plates under different aging treatment conditions. It can be found that the strength of the steel sheet is significantly improved after aging treatment. This is the results of the precipitation which contributes to an increase of strength for the stainless steel. Table 2 shows the tensile properties of the experimental steel after different aging treatment. The optimal aging treatment process parameters is at $650^{\circ} \mathrm{C}$ for $2 \mathrm{~h}$, while the yield strength, the tensile strength and the elongation is $705.6 \mathrm{MPa}, 1002.3 \mathrm{MPa}$ and $37.8 \%$. When the aging temperature is lower than $650{ }^{\circ} \mathrm{C}$, there is almost no change at the grain boundary, fine $(\mathrm{Nb}, \mathrm{V})(\mathrm{C}, \mathrm{N})$ particles in the grain remain coherent or semi-coherent relationship with the matrix and strongly hinders dislocation slip during plastic deformation. When the aging temperature is higher than $650{ }^{\circ} \mathrm{C}$, the precipitated particles in the grain will increase and the coarsened particles gradually lose their coherent or semi-coherent relationship with the matrix, which greatly reduces the total interfacial energy and weakens the strengthening effect.


Figure 7. Stress-strain curve of the experimental steel after different aging treatment. (a) different temperatures with $2 \mathrm{~h}$, (b) $650{ }^{\circ} \mathrm{C}$ with different time.

Table 2. Tensile properties of the experimental steel after different aging treatment.

\begin{tabular}{cccc}
\hline Aging Treatment & Yield Strength/MPa & Tensile Strength/MPa & Elongation/\% \\
\hline $550^{\circ} \mathrm{C}, 2 \mathrm{~h}$ & 660 & 901 & 48 \\
$600^{\circ} \mathrm{C}, 2 \mathrm{~h}$ & 680 & 973 & 43 \\
$650^{\circ} \mathrm{C}, 2 \mathrm{~h}$ & 705 & 1002 & 38 \\
$700^{\circ} \mathrm{C}, 2 \mathrm{~h}$ & 693 & 963 & 37 \\
$750^{\circ} \mathrm{C}, 2 \mathrm{~h}$ & 676 & 931 & 32 \\
$650^{\circ} \mathrm{C}, 0.5 \mathrm{~h}$ & 661 & 898 & 48 \\
$650^{\circ} \mathrm{C}, 1 \mathrm{~h}$ & 693 & 971 & 42 \\
$650^{\circ} \mathrm{C}, 4 \mathrm{~h}$ & 685 & 979 & 38 \\
$650^{\circ} \mathrm{C}, 10 \mathrm{~h}$ & 672 & 965 & 34 \\
\hline
\end{tabular}

\subsection{Magnetic Properties}

Figure 8 shows the hysteresis loop of steel sheet sample under different aging treatment conditions. It can be seen that the hysteresis loops of the experimental steel are almost completely coincident and close to a perfect linear relationship, and no typical hysteresis loop occurs. It can be known from the microscopic analysis that since the precipitated phases are all face-centered cubic structures, no ferromagnetic phases exist. The relative magnetic permeability is calculated as 1.003 , which means the stainless steel has good low magnetic characteristics. When aging treatment is carried out under different conditions, the number and size of precipitates in the experimental steel are different. However, through the magnetic properties test, it is found that the hysteresis loop of the experimental 
steel after various aging treatments is still a straight line, showing paramagnetic properties. Therefore, the precipitates produced in the aging process of the experimental steel will not affect the paramagnetic properties of the experimental steel. Aging treatment will not destroy the paramagnetic stability of the experimental steel.
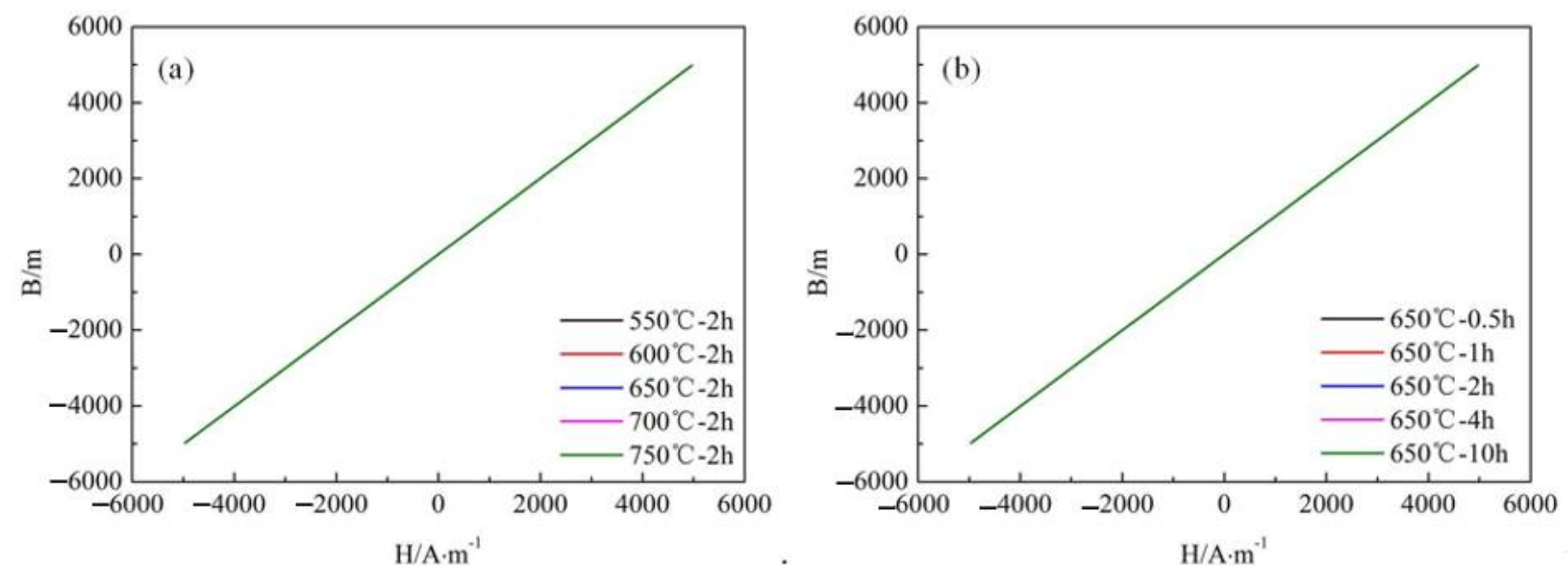

Figure 8. Hysteresis loop of experimental steel under different aging treatment conditions. (a) Different temperatures with $2 \mathrm{~h}$, (b) $650{ }^{\circ} \mathrm{C}$ with different time.

\section{Discussion}

\subsection{Precipitate in Aging Treatment}

In the conventional $\mathrm{Cr}-\mathrm{Ni}$ austenitic stainless steel, the precipitated phase include $\operatorname{MX}(\mathrm{M}=\mathrm{Nb}, \mathrm{V}, \mathrm{Ti}, \mathrm{X}=\mathrm{C}, \mathrm{N}), \mathrm{M}_{23} \mathrm{C}_{6}(\mathrm{M}=\mathrm{Fe}, \mathrm{Cr}), \mathrm{Z}$ phase $(\mathrm{Cr}(\mathrm{Nb}, \mathrm{V}) \mathrm{N})$, hard and brittle $\sigma$ phase ( $\mathrm{FeCr}$ ). In this experiment, combined with the TEM diffraction spot calibration, it can be further determined that the precipitated particles are $(\mathrm{Nb}, \mathrm{V})(\mathrm{C}, \mathrm{N})$ of the facecentered cubic structure and have a cube-on-cube orientation relationship with the austenite matrix. Z phase particles have a body-centered cubic (BCC) structure, which are easily formed in steels containing high $\mathrm{Cr}$, high $\mathrm{Nb}$ and high $\mathrm{N}$ [26]. Once the $Z$ phase arises, it will grow up at a rapid speed with the cost of MX-type carbonitrides, and it is difficult to control the size, which is not beneficial to the strength of the steel. The precipitation of $Z$ phase needs high temperature environment or long time aging [31]. In this study, through the energy spectrum analysis of $(\mathrm{Nb}, \mathrm{V})(\mathrm{C}, \mathrm{N})$ particles aged at $650{ }^{\circ} \mathrm{C}$ for $10 \mathrm{~h}$ (Figure $9 \mathrm{a}, \mathrm{b}$ ) and aged at $750^{\circ} \mathrm{C}$ for $2 \mathrm{~h}$ (Figure $9 \mathrm{c}, \mathrm{d}$ ), 11 during the whole aging process, and the composition of $\mathrm{Cr}$ always keeps a low content, which is consistent with the thermodynamic calculation results. The results show that there was no Z-phase particles in the aging process.

Formation of an intermetallic phase known as $\sigma$-phase is a severe problem when using standard austenitic stainless steels at elevated temperatures [32,33]. In the initial state of austenitic stainless steel which contains $0.18 \%$ carbon will be present a ferrite $\alpha$-phase. As a result, at the temperature of $450-550{ }^{\circ} \mathrm{C}$, stratification of the high-chromium $\alpha$-solid solution will occur and a brittle $\sigma$-phase is formed. Therefore, aging is best carried out in the temperature range $600-650{ }^{\circ} \mathrm{C}$, then the microstructure of the steel will be precisely balanced. In this paper, due to the high amount of $\mathrm{N}(0.368 \%)$ and the higher affinity for $\mathrm{Nb}$, $\mathrm{V}$ than that of carbon, the nitrogen in experimental steel is consumed for the stabilization of austenite partially and for the formation of nitride phases with niobium and vanadium firstly. At the same time, the affinity of $\mathrm{Nb}$ and $\mathrm{V}$ for $\mathrm{C}$ is stronger than that of $\mathrm{Cr}$ and $\mathrm{Mo}$, which is not conducive to the formation of intergranular precipitation phase $\mathrm{M}_{23} \mathrm{C}_{6}$. By reducing the $\mathrm{Cr}$-depleted region and the diffusion rate of $\mathrm{Cr}$, the probability of $\sigma$ phase formation decrease. 

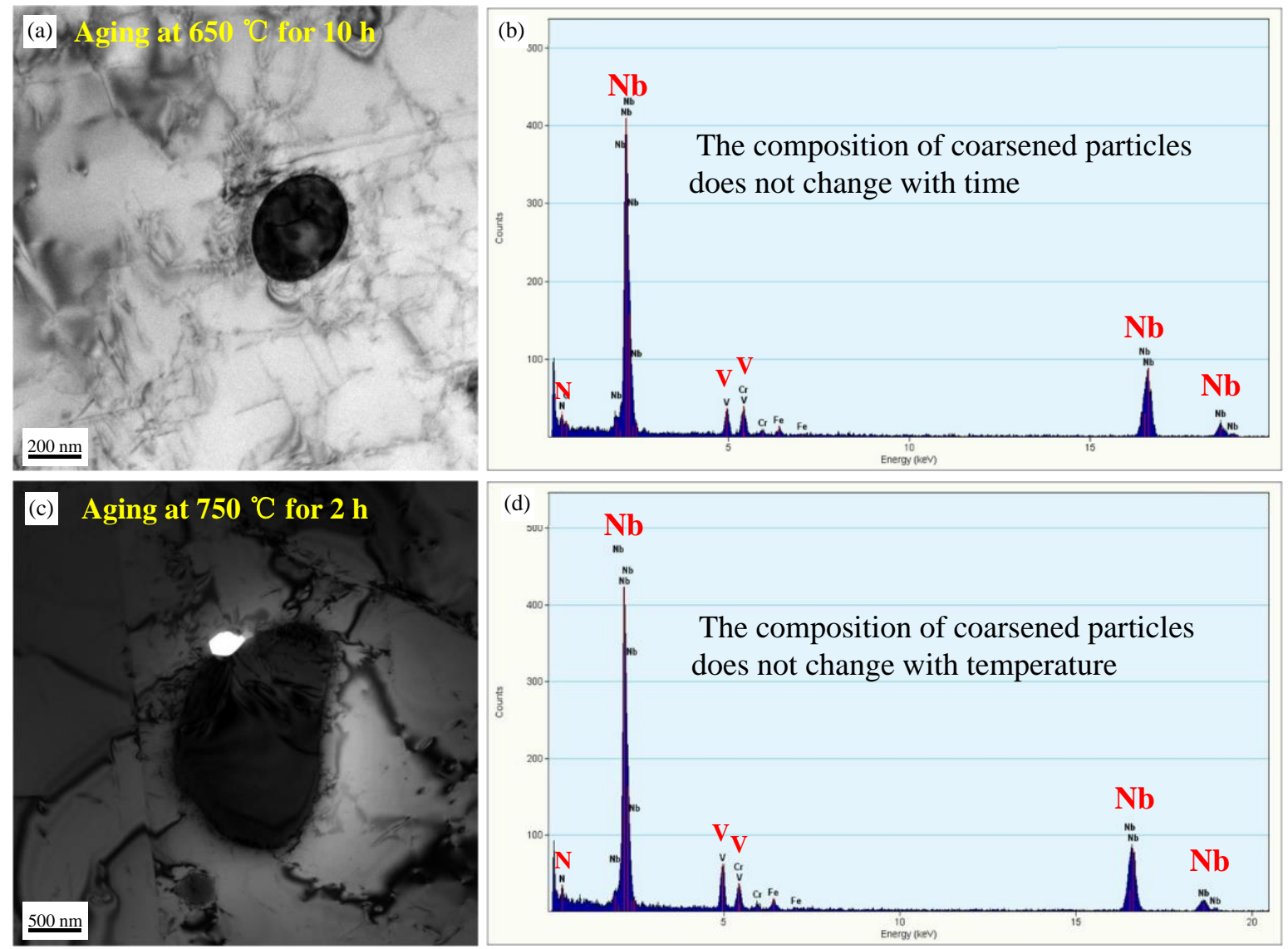

Figure 9. TEM and EDS analysis of elements in the steel after aging treatment. $(\mathbf{a}, \mathbf{b})$ aging at $650{ }^{\circ} \mathrm{C}$ for $10 \mathrm{~h},(\mathbf{c}, \mathbf{d})$ aging at $750{ }^{\circ} \mathrm{C}$ for $2 \mathrm{~h}$.

\subsection{Coarsening of the $(N b, V)(C, N)$ Precipitates}

The precipitation and dissolution of second phase particles in the steel is actually a diffusion process. When the temperature is high enough or the time is long enough, the coarsening of precipitates is unavoidable [22,24], which weaken the strengthening effect. According to the LSW theory proposed by Lifshitz, Slyozov and Wagner $[23,25]$, the relationship between the size of roughened particles and time is shown in Equation (1).

$$
r_{t}^{3}-r_{0}^{3}=k t k=\frac{8 D \sigma C_{\alpha}(\infty) V_{m}}{9 R T}
$$

where, $r_{t}$ is the average radius of the precipitated particles, $\mathrm{m} ; r_{0}$ is the initial average radius of the precipitated phase, $\mathrm{m} ; k$ is the roughening rate, $\mathrm{m}^{3} / \mathrm{s} ; D$ is the diffusion coefficient of the solute atom in the matrix; $\sigma$ is the interfacial energy between precipitated phase and austenite matrix, $\mathrm{J} / \mathrm{m}^{2} ; C_{\alpha}$ represents the equilibrium concentration of the solute atom at infinity from the precipitation phase, $\mathrm{mol} / \mathrm{m}^{3} ; V_{m}$ represents the molar volume fraction of precipitated phase, $\mathrm{m}^{3} / \mathrm{mol} ; \mathrm{T}$ is the Kelvin temperature, $\mathrm{K}$.

Since the experimental steel is solution treated before aging treatment, $r_{0}$ is negligible. Equation (1) can be expressed as Equation (2).

$$
r_{t}^{3} \approx k t
$$

The size of precipitates in the aging treatment are calculated by Image Pro Plus image processing software. The change of the coarsening rate and average radius of the intragranular particles is shown in Figure 10. It can be seen that the roughening rate is low at 550, 600 and $650{ }^{\circ} \mathrm{C}$ (Figure 10a), which can be ascribed to the value of $D$ 
and $V_{m}$ in Equation (1) is small at $650{ }^{\circ} \mathrm{C}$. While the aging temperature exceeds $650{ }^{\circ} \mathrm{C}$, the coarsening rate increases rapidly. Because the activity of the solute atoms increases, the diffusion is sufficient. The small-sized $(\mathrm{Nb}, \mathrm{V})(\mathrm{C}, \mathrm{N})$ particles begin to dissolve, reducing the total surface area of precipitated particles in the grain, which in turn reduces the interfacial energy, with the temperature increasing the Ostwald ripening phenomenon occurs. The average radius of intragranular $(\mathrm{Nb}, \mathrm{V})(\mathrm{C}, \mathrm{N})$ particles at $650^{\circ} \mathrm{C}$ for $0.5-10 \mathrm{~h}$ by calculation and experimental was shown in Figure 10b. It can be found that the calculated value is consistent well with the predicted value.
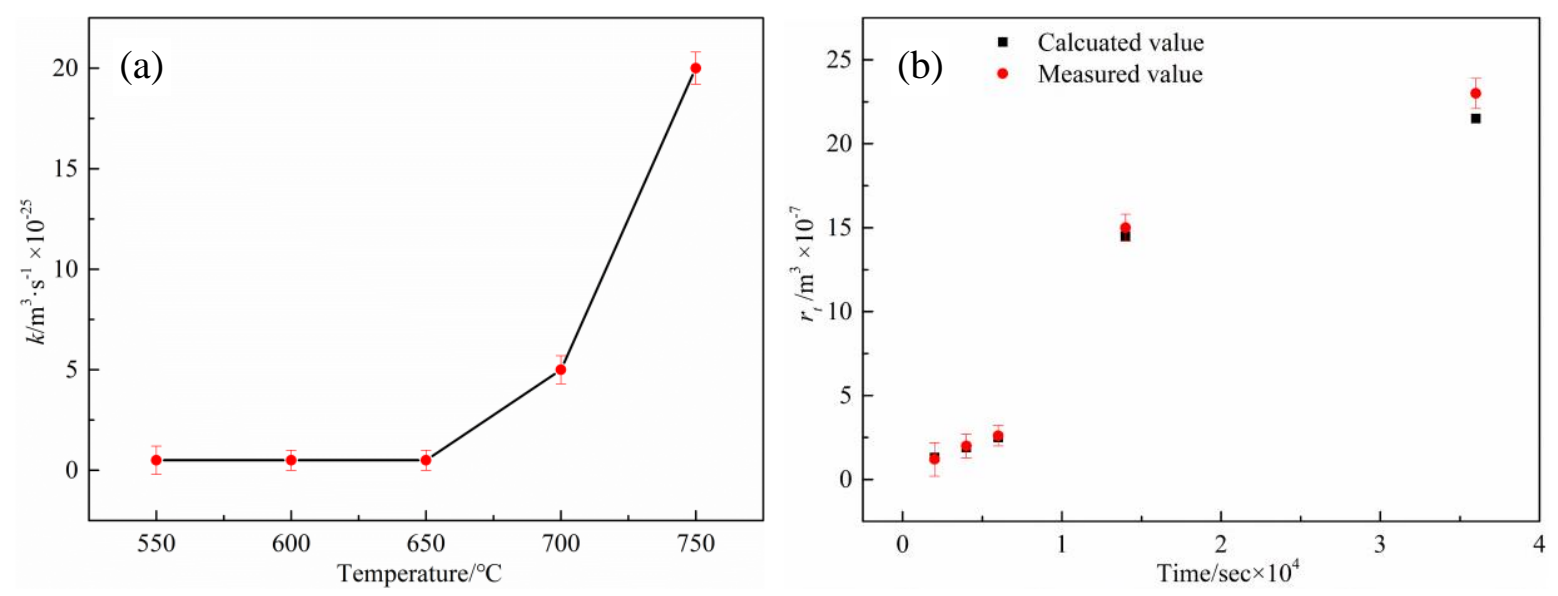

Figure 10. Calculation of coarsening rate of precipitates (a) at different aging temperatures with $2 \mathrm{~h}$, (b) comparison of the calculated and measured precipitates inside the grains at $650{ }^{\circ} \mathrm{C}$ with different aging times.

\subsection{Effect of Precipitates on Mechanical Properties}

In this study, the strength of the experimental steel increased after different aging treatment temperature and $650{ }^{\circ} \mathrm{C}$ with different time at as shown in Figure 11. The maximum strength existed in the process of aging at $650{ }^{\circ} \mathrm{C}$ for $2 \mathrm{~h}$. When the aging temperature is lower than $650{ }^{\circ} \mathrm{C}$ (Figure 11a) or the aging time is less than $2 \mathrm{~h}$ (Figure 11b), the amount of $(\mathrm{Nb}, \mathrm{V})(\mathrm{C}, \mathrm{N})$ particles increases gradually with the rising of temperature or time, and the size of $(\mathrm{Nb}, \mathrm{V})(\mathrm{C}, \mathrm{N})$ particles remain unchanged. It keeps coherent or semi-coherent relationship with the matrix. There is a high-energy strain field between the second phase particles and the matrix, which can strongly block the dislocation slip in the process of plastic deformation [34]. It is called coherent mechanism in the second phase strengthening. When the aging temperature is higher than $650{ }^{\circ} \mathrm{C}$ or time is higher than $2 \mathrm{~h}$, the coarsened particles gradually lose the coherent or semi coherent relationship with the matrix. When the coherent relationship is lost, the total interface energy will be greatly reduced, and the total amount of reduction will exceed the elastic strain energy generated by coherent strengthening, that is, the high energy region is lost, and the strengthening effect is weakened [35].

There existed Orowan or cutting mechanism on interaction between dislocations and particles for precipitation strengthening [36], which mechanism plays a leading role depends on the size of the particles. They are all related to the size distribution and volume fraction of particles. 

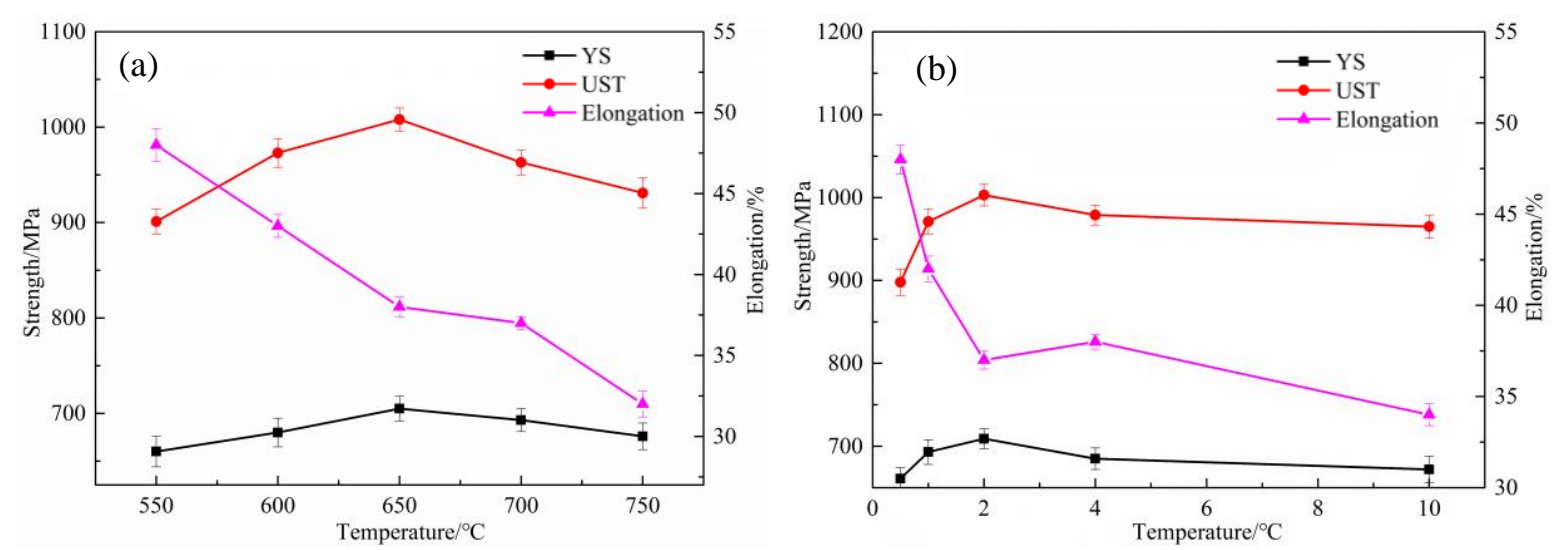

Figure 11. Influence of aging parameters on YS, UTS and elongation for the experimental steel. (a) Aging at different temperatures with $2 \mathrm{~h},(\mathbf{b})$ aging at $650{ }^{\circ} \mathrm{C}$ with different time.

The pinning effect of precipitated particles on dislocation is shown in Equation (3) [36,37]:

$$
\Delta \tau=\frac{\alpha G b}{\lambda}
$$

where, $\alpha$ is a constant; $G$ is the shear modulus, MPa; $b$ is the Bernoulli vector of dislocation, $\mathrm{nm} . \lambda$ is the average free path of particle motion, as shown in Equation (4) [38]:

$$
\lambda=\frac{d\left(1-f^{1 / 3}\right)}{f^{1 / 3}}
$$

where, $d$ is the average diameter of precipitated particles, $\mathrm{m} ; f$ is the volume fraction of precipitated phase, $\%$. At low temperature or early aging stage, combined with the calculation of microstructure and particle coarsening rate, it can be seen that the particles keep small size and have enough stability, and then increase the volume fraction $\mathrm{f}$ of the second phase, so it has a significant strengthening effect. The microstructure observation shows that the coarsening rate increases with the increase of temperature or time, the precipitation amount and volume fraction of particles decrease and the average free path $\lambda$ increases, which leads to the decrease of the pinning effect of particles on dislocations in the plastic deformation process of the whole system [39].

Figure 12 shows the tensile fracture morphology of steel plate under different heat treatment conditions. As shown in Figure 12a, after solution treatment, the fracture surface is dominated by large and deep equiaxed dimples, showing good ductile fracture characteristics, which is a typical fracture mode of micropore aggregation. As shown in Figure $12 \mathrm{~b}$, after aging at $650^{\circ} \mathrm{C}$ for $2 \mathrm{~h}$, the fracture mode is still ductile fracture, but the average diameter and average depth of dimple are greatly reduced compared with that of solution treated fracture. From the enlargement of Figure 12b, there are a large number of particles at the bottom of the dimple, which indicates that dislocations pile up around the second phase particles during the tensile process, resulting in local deformation and detachment from the austenite matrix. After aging at $650{ }^{\circ} \mathrm{C}$ with $10 \mathrm{~h}$ (Figure 12c) and at $750{ }^{\circ} \mathrm{C}$ with $2 \mathrm{~h}$ (Figure 12d), brittle fracture characteristics such as intergranular fracture and flat cleavage surface appear, which belong to the mixed fracture mode of toughness and brittleness. With the increase of aging temperature and aging time, the precipitates on grain boundary begin to gather, the size of precipitates in grain becomes larger and the coherent relationship with matrix is lost. On the one hand, the crystal structure of the coarse intermetallic compound is different from that of the matrix, so it is easy to produce the uncoordinated deformation in the plastic deformation, resulting in the stress concentration at the interface between the intermetallic compound and the matrix, forming the crack source [40,41]. On the other hand, the mechanism of dislocation slip changes from shear to bypass. When intragranular dislocation slip encounters precipitated phase, 
the critical shear stress required to bypass precipitated phase is lower than that required by shear. Dislocations tend to bypass precipitates and gather at grain boundaries, leading to stress concentration, intergranular fracture and brittle fracture.


Figure 12. Fracture morphology of tensile specimens after different aging treatment. (a) Solution treatment, (b) aging at $650{ }^{\circ} \mathrm{C}$ with $2 \mathrm{~h}$ after solution treatment, the precipitates at the bottom of the dimple are indicated by red arrows, (c) aging at $650{ }^{\circ} \mathrm{C}$ with $10 \mathrm{~h}$ after solution treatment, cleavage fracture is marked by yellow circle, (d) aging at $750{ }^{\circ} \mathrm{C}$ with $2 \mathrm{~h}$ after solution treatment, intergranular fracture is marked by yellow circle.

According to the change trend of tensile properties with aging temperature and time, it can be seen that the plasticity presents a downward trend, which is mainly caused by two factors. Firstly, particles coarsen rapidly during high temperature or long aging, which weakens the effect of particles on moving dislocation pinning during plastic deformation; secondly, non-coherent $\mathrm{M}_{23} \mathrm{C}_{6}$ is produced at the trigeminal grain boundary. As we all know, the existence of non-coherent $\mathrm{M}_{23} \mathrm{C}_{6}$ will greatly reduce the toughness of the material, because the coarse and non-coherent $\mathrm{M}_{23} \mathrm{C}_{6}$ seriously weakens the bond strength between the original grain boundaries [42,43], and then leads to the rapid crack initiation in the process of tensile deformation and reduces the plasticity of the steel plate.

\section{Conclusions}

The effect of aging on the precipitates, mechanical and magnetic properties of $\mathrm{Fe}-21 \mathrm{Cr}-$ $15 \mathrm{Ni}-6 \mathrm{Mn}-\mathrm{Nb}$ low magnetic stainless steel was investigated.

(1) When the aging treatment is at $500-650{ }^{\circ} \mathrm{C}$ for $2 \mathrm{~h}$, the fine $(\mathrm{Nb}, \mathrm{V})(\mathrm{C}, \mathrm{N})$ is diffused with the temperature increases, which is in a coherent or semi-coherent relationship with the matrix. When the temperature exceeds $650{ }^{\circ} \mathrm{C}$, the $(\mathrm{Nb}, \mathrm{V})(\mathrm{C}, \mathrm{N})$ particles gradually lose their coherent relationship with the matrix, the grain boundary is gradually coarsened 
and chain-like distribution of $\mathrm{M}_{23} \mathrm{C}_{6}$ occur, which is in a non-coherent relationship with the matrix. During the whole aging process, the $\mathrm{Z}$ phase and the $\sigma$ phase do not appear.

(2) The coarsening behavior of intragranular $(\mathrm{Nb}, \mathrm{V})(\mathrm{C}, \mathrm{N})$ particles during the aging treatment was analyzed by LSW theory. It was found that the roughening rate rises rapidly when the aging temperature exceeded $650{ }^{\circ} \mathrm{C}$. The particle size of the precipitated particles at $650{ }^{\circ} \mathrm{C}$ with different time was calculated. The theoretical values of the precipitated particles in the grain are consistent with the measured values.

(3) Under the aging treatment process at $650{ }^{\circ} \mathrm{C}$ with $2 \mathrm{~h}$, the yield strength, tensile strength, elongation and the relative magnetic permeability of the experimental steel is 705.6 $\mathrm{MPa}, 1002.3 \mathrm{MPa}, 37.8 \%$ and 1.003. It demonstrates that the precipitates through aging treatment improved the strength and kept low magnetic property.

Author Contributions: C.L. conceived and designed the experiments; K.L. performed the experiments and wrote the paper; Y.S. performed the experiments; J.D. and J.R. analyzed the data. All authors have read and agreed to the published version of the manuscript.

Funding: This work was funded by the joint project from the National Natural Science Foundation of China and Baowu Steel Group Co., Ltd., (Grant No. U1660205).

Institutional Review Board Statement: Not applicable.

Informed Consent Statement: Not applicable.

Data Availability Statement: Not applicable.

Conflicts of Interest: The authors declare no conflict of interest.

\section{References}

1. Xiong, Y.; He, T.; Wang, J.; Lu, Y.; Chen, L.; Ren, F.; Liu, Y.; Volinsky, A.A. Cryorolling effect on microstructure and mechanical properties of Fe-25Cr-20Ni austenitic stainless steel. Mater. Des. 2015, 88, 398-405. [CrossRef]

2. Lo, K.H.; Shek, C.H.; Lai, J.K.L. Recent developments in stainless steels. Mater. Sci. Eng. R 2009, 65, 39-104. [CrossRef]

3. Terada, M.; Saiki, M.; Costa, I.; Padilha, A.F. Microstructure and intergranular corrosion of the austenitic stainless steel. J. Nucl. Mater. 2006, 358, 40-46. [CrossRef]

4. Sun, H.; Sun, Y.; Zhang, R.; Wang, M.; Tang, R.; Zhou, Z. Study on hot workability and optimization of process parameters of a modified 310 austenitic stainless steel using processing maps. Mater. Des. 2015, 67, 165-172. [CrossRef]

5. Song, Y.L.; Li, C.S.; Li, B.Z.; Han, Y.H. Microstructure characterisation of Fe-21Cr-15Ni-Nb-V non-magnetic austenitic stainless steel during hot deformation. Mater. Sci. Technol. 2018, 34, 1639-1648. [CrossRef]

6. Li, C.S.; Ma, B.; Song, Y.; Zheng, J.J.; Wang, J.K. Grain refinement of non-magnetic austenitic steels during asymmetrical hot rolling process. J. Mater. Sci. Technol. 2017, 13, 1572-1576. [CrossRef]

7. Izuta, Y.; Prasad, K.; Itoa, A.; Tanak, M.; Torizuka, S. Transmission X ray diffraction characterization of deformation induced martensite in 301 and 304 stainless steels rolled at 77K: Role of grain size. Mater. Sci. Eng. A 2020, 794, 139984. [CrossRef]

8. Sun, G.S.; Du, L.X.; Hu, J.; Zhang, B.; Misra, R.D.K. On the influence of deformation mechanism during cold and warm rolling on annealing behavior of a 304 stainless steel. Mater. Sci. Eng. A 2019, 746, 341-355. [CrossRef]

9. Odnobokova, M.; Belyakov, A.; Enikeev, N.; Molodov, D.; Kaibyshev, R. Annealing behavior of a 304L stainless steel processed by large strain cold and warm rolling. Mater. Sci. Eng. A 2017, 689, 370-383. [CrossRef]

10. Wu, H.; Huang, S.; Zhao, C.; Zhu, H.; Xie, Z.; Tu, C.; Li, X. Microstructures and mechanical properties of in-situ FeCrNiCu high entropy alloy matrix composites reinforced with $\mathrm{NbC}$ particles. Intermetallics 2020, 127, 106983. [CrossRef]

11. Wen, D.H.; Li, Z.; Jiang, B.B.; Wang, Q.; Chen, G.Q.; Tang, R.; Zhang, R.Q.; Dong, C.; Liaw, K.P. Effects of Nb/Ti/V/Ta on phase precipitation and oxidation resistance at $1073 \mathrm{k}$ in alumina-forming austenitic stainless steels. Mater. Charact. 2018, 144, 86-98. [CrossRef]

12. Yamamoto, Y.; Takeyama, M.; Lu, Z.P.; Liu, C.T.; Evans, N.D.; Maziasz, P.J.; Brady, M.P. Alloying effects on creep and oxidation resistance of austenitic stainless steel alloys employing intermetallic precipitates. Intermetallics 2008, 16, 453-462. [CrossRef]

13. Zhao, W.X.; Zhou, D.Q.; Jiang, S.H.; Wang, H.; Wu, Y.; Liu, X.J.; Wang, X.Z.; Lu, Z.P. Ultrahigh stability and strong precipitation strengthening of nanosized $\mathrm{NbC}$ in alumina-forming austenitic stainless steels subjecting to long-term high-temperature exposure. Mater. Sci. Eng. A 2018, 738, 295-307. [CrossRef]

14. Jiao, Z.B.; Luan, J.H.; Miller, M.K.; Chung, Y.W.; Liu, C.T. Co-Precipitation of nanoscale particles in steels with ultra-high strength for a new era. Mater. Today 2017, 20, 142-154. [CrossRef]

15. Zhou, D.Q.; Zhao, W.X.; Mao, H.H.; Hu, Y.X.; Xu, X.Q.; Sun, X.Y.; Lu, Z.P. Precipitate characteristics and their effects on the high-temperature creep resistance of alumina-forming austenitic stainless steels. Mater. Sci. Eng. A 2015, 622, 91-100. [CrossRef] 
16. Yamamoto, Y.; Brady, M.P.; Lu, Z.P.; Takeyama, M.; Maziasz, P.J.; Liu, C.T.; Pint, B.A. Alumina-Forming austenitic stainless steels strengthened by laves phase and MC carbide precipitates. Metall. Mater. Trans. A 2007, 38, 2737-2746. [CrossRef]

17. Taneike, M.; Abe, F.; Sawada, K. Creep-Strengthening of steel at high temperatures using nano-sized carbonitride dispersions. Nature 2003, 424, 294-296. [CrossRef] [PubMed]

18. Fujita, N.; Ohmura, K.; Yamamoto, A. Changes of microstructures and high temperature properties during high temperature service of niobium added ferritic stainless steels. Mater. Sci. Eng. A 2003, 351, 272-281. [CrossRef]

19. Han, K.; Vasquez, A.A.; Xin, Y.; Kalu, P.N. Microstructure and tensile properties of nanostructured Cu-25wt\%Ag. Acta Mater. 2003, 51, 767-780. [CrossRef]

20. Trotter, G.; Baker, I. Orientation relationships of Laves phase and NiAl particles in an AFA stainless steel. Philos. Mag. 2015, 95, 4078-4094. [CrossRef]

21. Li, Y.Q.; Gong, Y.H. Effects of magnesium and long-term ageing on intragranular precipitation in Fe-Cr-Ni-Mn-Mo-V-Nb superalloy. J. Mater. Sci. 1992, 27, 6641-6645.

22. Trotter, G.; Baker, I. The effect of aging on the microstructure and mechanical behavior of the alumina-forming austenitic stainless steel Fe-20Cr-30Ni-2Nb-5Al. Mater. Sci. Eng. A 2015, 627, 270-276. [CrossRef]

23. Han, J.; Li, H.J.; Barbaro, F.; Jiang, L.Z.; Zhu, Z.X.; Xu, H.G.; Ma, L. Precipitation and impact toughness of Nb-V stabilized 18Cr-2Mo ferritic stainless steel during isothermal aging. Mater. Sci. Eng. A 2014, 612, 63-70. [CrossRef]

24. Sim, G.M.; Ahn, J.C.; Hong, S.C.; Lee, K.J.; Lee, K.S. Effect of $\mathrm{Nb}$ precipitate coarsening on the high temperature strength in Nb containing ferritic stainless steels. Mater. Sci. Eng. A 2005, 396, 159-165. [CrossRef]

25. Song, Y.L.; Li, C.S.; Li, B.Z.; Han, Y.H. Grain character and mechanical properties of Fe-21Cr-15N-6Mn-Nb non-magnetic stainless steel after solution treatment. Mater. Sci. Eng. A 2019, 742, 662-671. [CrossRef]

26. Ha, V.T.; Jung, W.S. Evolution of precipitate phases during long-term isothermal aging at $1083 \mathrm{k}\left(810{ }^{\circ} \mathrm{C}\right)$ in a new precipitationstrengthened heat-resistant austenitic stainless steel. Metall. Mater. Trans. A 2012, 43, 3366-3378. [CrossRef]

27. Danielsen, H.K.; Hald, J. On the nucleation and dissolution process of Z-phase $\mathrm{Cr}(\mathrm{V}, \mathrm{Nb}) \mathrm{N}$ in martensitic $12 \%$ Cr steels. Mater. Sci. Eng. A 2009, 505, 169-177. [CrossRef]

28. Danielsen, H.K.; Hald, J. Behaviour of Z phase in 9-12 \% Cr steels. Energy Mater. 2006, 1, 49-57. [CrossRef]

29. Solenthaler, C.; Ramesh, M.; Uggowitzer, P.J.; Spolenak, R. Precipitation strengthening of Nb-stabilized TP347 austenitic steel by a dispersion of secondary $\mathrm{Nb}(\mathrm{C}, \mathrm{N})$ formed upon a short-term hardening heat treatment. Mater. Sci. Eng. A 2015, 647, 294-302. [CrossRef]

30. Ou, P.; Xing, H.; Wang, X.L.; Sun, J. Tensile yield behavior and precipitation strengthening mechanism in Super304H steel. Mater Sci. Eng. A 2014, 600, 171-175. [CrossRef]

31. Sawada, K.; Tabuchi, M.; Hongo, H.; Watanabe, T.; Kimura, K. Z-Phase formation in welded joints of high chromium ferritic steels after long-term creep. Mater. Charact. 2008, 59, 1161-1167. [CrossRef]

32. Peng, B.C.; Zhang, H.X.; Hong, J.; Gao, J.Q.; Zhang, H.Q.; Wang, Q.J.; Li, J.F. The effect of $\mathrm{M}_{23} \mathrm{C}_{6}$ on the high-temperature tensile strength of two austenitic heat-resistant steels: 22Cr-25Ni-Mo-Nb-N and 25Cr-20Ni-Nb-N. Mater. Sci. Eng. A 2011, 528, 3625-3629. [CrossRef]

33. Schwind, M.; Källqvist, J.; Nilsson, J.O.; Ågren, J.; Andrén, H.O. o-phase precipitation in stabilized austenitic stainless steels. Acta Mater. 2000, 48, 2473-2481. [CrossRef]

34. Ahmadi, M.R.; Povoden-Karadeniz, E.; Sonderegger, B.; Öksüz, K.I.; Falahati, A.; Kozeschnik, E. A model for coherency strengthening of large precipitates. Scr. Mater. 2014, 84, 47-50. [CrossRef]

35. Mannan, P.; Gilberto, C.; Pereloma, E.V. The effect of $\mathrm{Nb}$ solute and $\mathrm{NbC}$ precipitates on dynamic and metadynamic recrystallisation in Ni-30Fe-Nb-C model alloys. Mater. Sci. Eng. A 2017, 700, 116-131. [CrossRef]

36. Futamura, Y.; Tsuchiyama, T.; Takaki, S. Strengthening mechanism of Cu bearing heat resistant martensitic steels. ISIJ Int. 2001, 41, 106-110. [CrossRef]

37. Peng, B.; Zhang, H.; Hong, J.; Gao, J.; Wang, Q.; Zhang, H. Effect of aging on the impact toughness of $25 \mathrm{Cr}-20 \mathrm{Ni}-\mathrm{Nb}-\mathrm{N}$ steel. Mater. Sci. Eng. A 2010, 527, 1957-1961. [CrossRef]

38. Kimura, H. Precipitation behavior and 2-step aging of 17-4PH stainless steel. Tetsu-to-Hagane 2000, 86, 343-348. [CrossRef]

39. Zhang, Y.; Zhu, L.; Qi, A.; Lu, Z. Microstructural evolution and the effect on mechanical properties of s30432 heat-resistant steel during aging at $650{ }^{\circ} \mathrm{C}$. ISIJ Int. 2010, 50, 596-600. [CrossRef]

40. Atas, M.S.; Ildirim, M.Y. Morphological development, coarsening, and oxidation behavior of Ni-Al-Nb superalloys. J. Mater. Eng. Perform. 2020, 29, 4421-4434. [CrossRef]

41. Du, Y.; Li, X.; Zhang, X.; Chung, Y.W.; Isheim, D.; Vaynman, S. Design and characterization of a heat-resistant ferritic steel strengthened by $\mathrm{mx}$ precipitates. Metall. Mater. Trans. A 2020, 51, 638-647. [CrossRef]

42. Voorhees, P.W. Ostwald ripening of two-phase mixtures. Annu. Rev. Mater. Res. 1992, 22, 197-215. [CrossRef]

43. Lifshitzl, M.; Slyozov, V.V. The kinetics of precipitation from supersaturated solid solutions. J. Phys. Chem. Solids 1961, 19, 35-50. [CrossRef] 